\title{
Role of the ACTH/MC2R System in the Hair Cycle in Mice
}

\author{
Keiichi Hiramoto ${ }^{*}$, Kumi Orita ${ }^{2}$, Yurika Yamate', Emiko Kasahara² \\ ${ }^{1}$ Department of Pharmaceutical Science, Suzuka University of Medical Science, Mie, Japan \\ ${ }^{2}$ Department of Physiology, Osaka City University Graduate School of Medicine, Osaka, Japan \\ Email: "hiramoto@suzuka-u.ac.jp
}

Received 22 April 2016; accepted 21 June 2016; published 24 June 2016

Copyright (C) 2016 by authors and Scientific Research Publishing Inc.

This work is licensed under the Creative Commons Attribution International License (CC BY).

http://creativecommons.org/licenses/by/4.0/

(c) (i) Open Access

\begin{abstract}
Adrenocorticotropin hormone (ACTH), which is secreted in response to psychological stress, plays an important role in the hair cycle. This study examined the mechanism by which ACTH affects the hair cycle using mice deficient in melanocortin receptor-2(MC2R $\left.\mathrm{R}^{-/-}\right)$, which is a main receptor for ACTH. We observed the hair cycle using female MC2R ${ }^{-/-}$mice at 15 weeks old and five days old to determine whether there were any age-dependent differences. The 15-week-old $\mathrm{MC}^{-1} \mathrm{R}^{-/-}$mice showed the anagen phase for all mice. On the other hand, all of the MC2 $\mathrm{R}^{+/+}$mice showed the telogen phase at the same age. Moreover, in the five-day-old mice, the hair growth of the MC2 $\mathrm{R}^{-/-}$mice occurred earlier than in the $\mathrm{MC}^{2} \mathrm{R}^{+/+}$mice. Both the 15-week-old and five-day-old $\mathrm{MC}^{-1} \mathrm{R}^{-/-}$mice had higher levels of ACTH and alpha-melanocyte stimulating hormone in the blood than did the

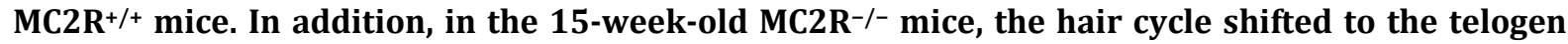
phase following the administration of a cyclic guanosine monophosphate (cGMP) inhibitor and MC1R/MC5R inhibitor. In the five-day-old MC2R-/- mice, the hair growth was slowed by the administration of corticosterone. These results suggest that the ACTH/MC2R system has an important role in the hair cycle.
\end{abstract}

\section{Keywords}

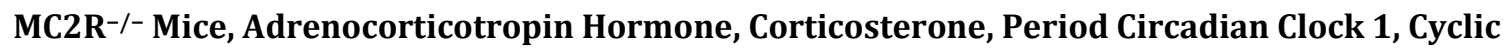
Guanosine Monophosphate

\section{Introduction}

In response to psychological stress, corticotropin-releasing hormone (CRH) is secreted from the hypothalamus, and CRH leads to the secretion of adrenocorticotropin hormone (ACTH) from the pituitary gland and local tissues

"Corresponding author. 
[1]. In the skin, CRF- or CRH-led signaling systems control the epidermal barrier function, as well as the skin immune, pigmentation, adnexal, and dermal functions necessary to maintain local and systemic homeostasis [2]. Furthermore, ACTH stimulates adrenal glucocorticoid biosynthesis and serection via the membrane-bound specific receptor, the melanocortine 2 receptor (MC2R) [3]. This action is a psychological stress management response which induces immunosuppression [4]. It is known that stress exposure can affect the hair cycle [5]-[7].

The hair cycles consist of the anagen, catagen and telogen phases, and the regulation of each phase is gradually becoming understood. For example, it is now known that fibroblast growth factor 18 [8], transforming growth factor $\beta$ (TGF- $\beta$ ) [9], testosterone [10] etc. promote the telogen phase, while platelet-derived growth factor [11], insulin growth factor-1 [12], etc. are factors which promote the anagen phase. With regard to the relationship with psychological stress, the telogen stage is extended by foot shock stress in association with retardation of the induction of the anagen stage, and it has been reported that substance P participates in this phenomenon [13] [14]. In addition, it is known that the substance $\mathrm{P}$ is produced by reactive oxygen species (ROS), which also inhibit hair growth by inducing chronic restraint stress [15]. Moreover, in the hair follicle, the CRH receptor is expressed, and its expression is high in the anagen stage, but low in the catagen and telogen stages [16]. However, there have been few reports about the role of ACTH, which is downstream of CRH.

This present study evaluated the relationship between ACTH and the hair cycle using MC2R deficient $\left(\mathrm{MC}^{-1-} \mathrm{R}^{-1}\right.$ ) mice. This research considers the influence of signal transmission via MC2R. The ACTH signal is transmitted via both MC2R and MC1R. However, we make reference to ACTH from the point of view of receptors for ACTH having the highest affinity to MC2R. Furthermore, we examined the role of ACTH using both adult mice and newborns with active hair growth.

\section{Materials and Methods}

\subsection{Animals}

Five-day-old female $\mathrm{MC}^{-1-}$ mice (B6/Balb mix background) and 15-week-old female $\mathrm{MC}^{-/-}$mice (National Center for Global Health and Medicine, Tokyo, Japan) were used for the experiments [17]. MC2R $\mathrm{R}^{+/+}$mice were used as control mice. The mice were kept on a 12-hour light/12-hour dark cycle at $23^{\circ} \mathrm{C} \pm 1^{\circ} \mathrm{C}$ under $\mathrm{SPF}$ conditions, and all animals were allowed free access to laboratory chow (CE-2, Oriental Yeast Co., Tokyo, Japan) and water during the experiments. There were ten mice per group. There are four possible fur colors for ${\mathrm{MC} 2 \mathrm{R}^{-/}}^{-1}$ mice; yellow, brown, black and white. In this experiment, we use the brown and yellow mice for the studies of 15-week-old mice, and we used the mice with white fur for the studies in the five-day-old mice. This study was carried out in strict accordance with the recommendations of the Guide for the Care and Use of Laboratory Animals of the Osaka City University Medical School. The protocol was approved by the Ethics of Animal Experiments committee of the Osaka City University of Medical Science (Approval number: 08113). All surgeries were performed under sodium pentobarbital anesthesia, and all effects were made to minimize suffering.

\subsection{Chemical Treatment}

\section{6-(phenylamino)-5,8-quinolinedione (LY83583) treatment}

LY83583 inhibits the production of soluble guanylate cyclase and cyclic guanosine monophosphate (cGMP). LY83583 (20 mg/kg; Cayman Chemical, Ann Arbor, MI) was suspended in a 1:175, solution of DMSO:PBS, which was administered intraperitoneally (i.p.) for two weeks from when the mice were 13 weeks old to when they were 15 weeks old or for four days, from when the mice were two days old to when they were five days old [18]. Control animals were treated with vehicle only.

\section{TGF- $\beta 1,2,3$ treatment}

Some of the mice were treated with an anti-TGF- $\beta 1,2,3$ antibody ( $2 \mathrm{mg} / \mathrm{kg}$, i.p.; R\&D Systems, Wiesbaden, Germany), and were treated during the same time period as with LY83583 [19]. Controls were treated with PBS.

\section{Agouti-related protein (AgRP) treatment}

Approximately $2.5 \mu \mathrm{g}$ of the MC1R and MC5R antagonist, AgRP (Peptide Institute Inc., Osaka, Japan), in 50 $\mu \mathrm{l}$ saline was injected for the same treatment period noted above. Saline was injected into the control mice [20].

\section{Corticosterone treatment}

Some of the mice were treated with the corticosterone (10 mg/kg S.C.; Wako, Osaka, Japan), again for two 
weeks from when the mice were 13 weeks old until they were 15 weeks old, or for four days from when they were two days old to when they were five days old [21]. Control animals were treated with corn oil.

\subsection{Quantification of the Levels of TGF- $\beta$, ACTH, Alpha-Melanocyte Stimulating Hormone $(\alpha-\mathrm{MSH}), \mathrm{CRH}$ and Corticosterone in the Plasma by Enzyme-Linked Immunosorbent Assays (ELISAs)}

We measured the levels of $\alpha$-MSH, ACTH, CRH and corticosterone in the blood of the mice when they were five days old and 15 weeks old. To measure the level of TGF- $\beta$, the blood samples were taken from the heart at $6 \mathrm{~h}$ after the final administration of treatment, and then the plasma was fractionated. The plasma levels of TGF- $\beta$, ACTH, $\alpha$-MSH, CRH and corticosterone were determined using commercial ELISA kits (TGF- $\beta$; Promega, Madison, WI; $\alpha$-MSH, ACTH and CRH; Phenix Pharmaceuticals Inc., Burlingame, CA; corticosterone; Assay Pro, St. Charles, MO) according to the manufacturers' instructions.

\subsection{Histology and Histomorphometry [22] [23]}

Formalin-fixed, paraffin-embedded sections were routinely stained with haematoxylin and eosin. We observed the depth of the hair follicle (hair-root pars-basilaris-ossis-occipitalis from the epidermis) at 100 to 400 times magnification using a light microscope. In addition, we measured the depth of the hair follicle using a micrometer in three visual fields (10 per visual field) at random in all mice and computed the average value.

\subsection{Preparation and Staining of Dorsal Skin}

Dorsal skin specimens were fixed in phosphate-buffered paraformaldehyde (4\%), embedded in frozen TissueTek OCT compound and cut into $5 \mu \mathrm{m}$-thick sections. The sections of the dorsal skin were washed in PBS and then were subsequently incubated overnight at $4^{\circ} \mathrm{C}$ with a rabbit anti-phosphodiesterase 9A (PDE9A) (1:400) polyclonal antibody (cGMP-specific 3'-5'-cyclic phosphodiesterase type 9; Novus Biologicals, Littleton, CO), rabbit anti-MC1R and rabbit anti-MC5R (1:100) polyclonal antibody (Chemicon, Temecula, CA), rabbit anti-period circadian clock 1 (Per1, 1:50) polyclonal antibody (Santa Crus Biotechnology Inc., Santa Cruz, CA), or rabbit anti-cryptochrome 1 (Cry1, 1:50) polyclonal antibody (Alpha Diagnostic, San Antonio, TX). The sections were then washed in PBS and incubated at room temperature for two hours with FITC-conjugated anti-rabbit immunoglobulin, TRITC-conjugated anti-rabbit immunoglobulin, or TRITC-conjugated anti-goat immunoglobulin (1:30; Dako Cytomation, Glostrup, Denmark). The expression levels of PDE9A, MC1R, MC5R, Per1 and Cry1 were evaluated immunohistochemically using a fluorescent microscope.

\subsection{Western Blot Analysis of the Dorsal Skin}

The dorsal skin samples were homogenized in lysis buffer containing $0.5 \%$ Nonidet P-40, 10\% glycerol, 137 $\mathrm{mM} \mathrm{NaCl}, 2 \mathrm{mM}$ ethylenediaminetetraacetic acid and $50 \mathrm{mM}$ Tris- $\mathrm{HCl}$ buffer (pH 8.0). Following centrifugation at $8000 \times \mathrm{g}$ for 10 minutes, the supernatant fractions were separated and stored at $-80^{\circ} \mathrm{C}$ until use. The stored dorsal skin specimens were subjected to $10 \%$ polyacrylamide gel electrophoresis (PAGE) in the presence of $0.1 \%$ SDS, and the electrophoresed proteins in the gel were transferred to an Immobilon membrane (Millipore, Bedford, MA). The membrane was then blocked with $5 \%$ skim milk at $4{ }^{\circ} \mathrm{C}$ overnight and subsequently incubated with primary antibodies against PDE9A (1:1000) polyclonal antibodies (Novus Biologicals, Littleton, CO), MC1R and MC5R (1:1000) polyclonal antibodies (Chemicon, Temecula, CA), Per1, (1:1000) polyclonal antibodies (Santa Crus Biotechnology Inc., Santa Cruz, CA), or Cry1 (1:1000) polyclonal antibodies (Alpha Diagnostic, San Antonio, TX) at $25^{\circ} \mathrm{C}$ for one hour following by horseradish peroxidase-conjugated secondary antibodies (DakoCytomation, Glostrup CA). The immune complexes thus formed were detected with enhanced chemiluminescence (ECL) reagents (GE Healthcare Bio-Sciences, Piscataway, NJ).

\subsection{Statistical Analysis}

All data are presented as the means \pm SD derived from 10 animals. The results obtained from the two animal groups were analyzed be either Student's $t$-test or an ANOVA using a computer software package. Differences were considered to be significant for values of $\mathrm{p}<0.05$. 


\section{Results}

\subsection{Hair Growth on the Dorsal Skin in MC2R $\mathrm{R}^{-/-}$Mice}

The hair cycle of the control mice when they were 10, 15 and 20 weeks old had stopped at the telogen phase, but the cycle in the $\mathrm{MC}_{2} \mathrm{R}^{-/-}$mice was maintained in the anagen phase (Figure 1(a)). The hair growth of the fiveday-old $\mathrm{MC}^{-1 /}$ mice was more active compared with that in the $\mathrm{MC}^{+1 /+}$ mice (Figure 1(b)). Moreover, the $\alpha$-MSH, ACTH and CRH level in the blood of ${\mathrm{MC} 2 \mathrm{R}^{-/}}^{-1}$ mice was high compared with that in $\mathrm{MC}^{\mathrm{R}} \mathrm{R}^{+/+}$mice (Figures 2(a)-(d), Figure 2(g) and Figure 2(h)). On the other hand, there were no significant differences in the corticosterone levels in the blood in the MC2R ${ }^{-/}$and MC2 ${ }^{+/+}$15-week-old and five-day-old mice (Figure 2(e) and Figure 2(f)). Based on these results, we used both the 15-week-old and five-day-old mice in the present study.

\subsection{Expression of PDE9A, MC1R, MC5R, Per1, Corticosterone Receptor, the TGF- $\beta 2$ Receptor and Cry1 in MC2 R ${ }^{-/-}$Mice}

To analyze the factors associated with the hair growth of $\mathrm{MC}^{-1-}$ mice, we investigated the expression of PDE9A, MC1R, MC5R, Per1, the corticosterone receptor, TGF- $\beta 2$ receptor and Cry1 in the skin. In the 15-

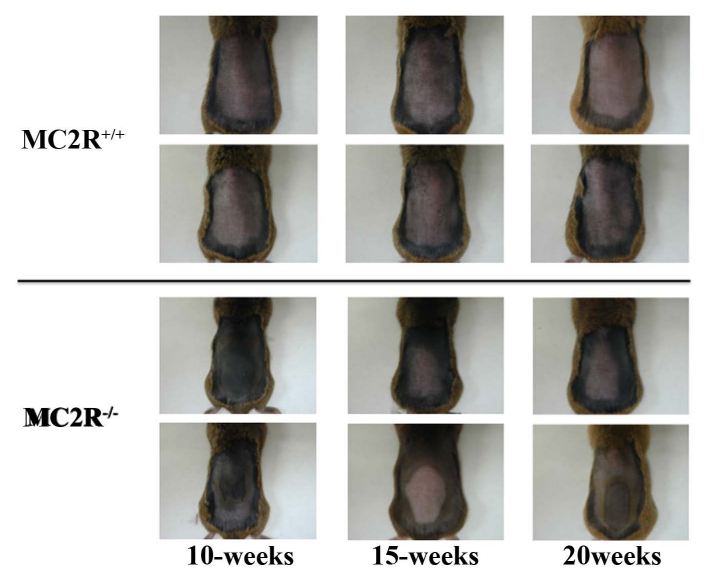

(a)
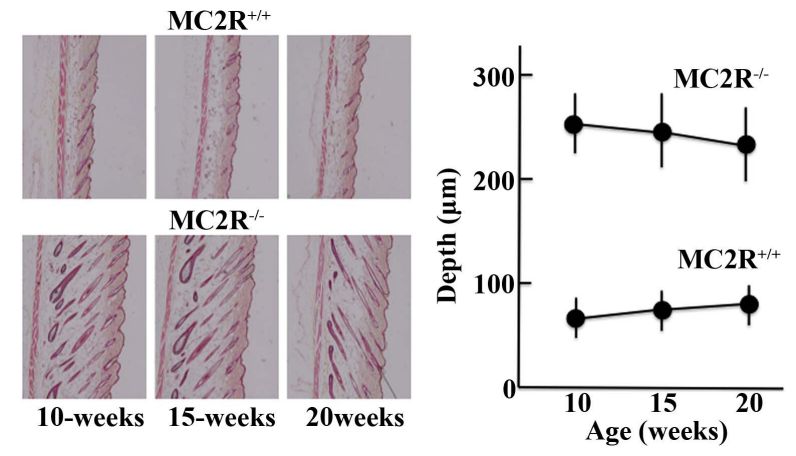

(b)

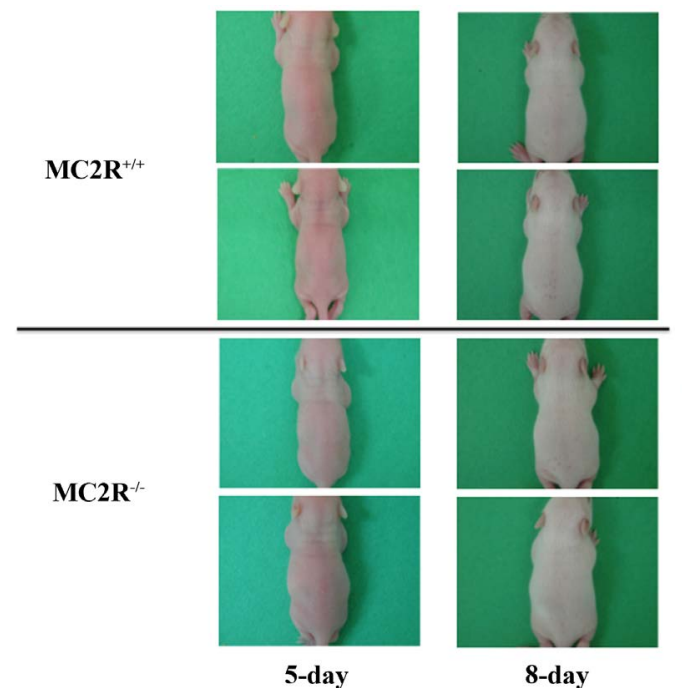

(c)

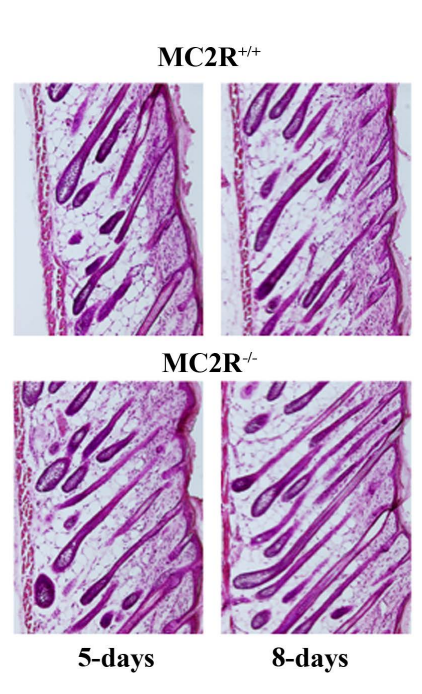

(d)

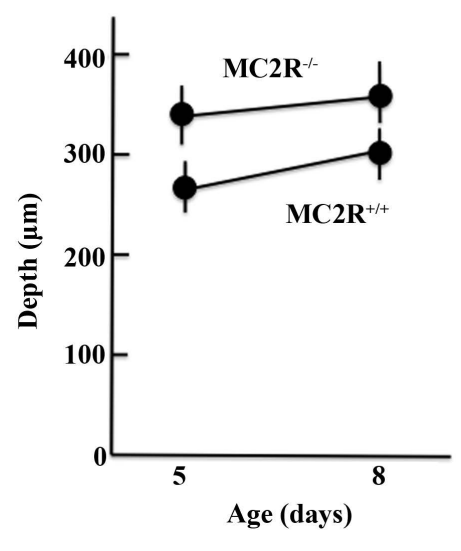

Figure 1. The hair growth of the dorsal skin in $\mathrm{MC}^{-1 /-}$ mice. The phases in the hair cycle of the MC2R $\mathrm{R}^{+/+}$and $\mathrm{MC} 2 \mathrm{R}^{-/-}$ mice when they were 10, 15 and 20 weeks old (a) and (b) and five and eight days old (c) and (d) are shown. The data show two typical experiments from 10 animals. The values are presented as the mean \pm SD derived from 10 animals. *, p $<0.05$. 


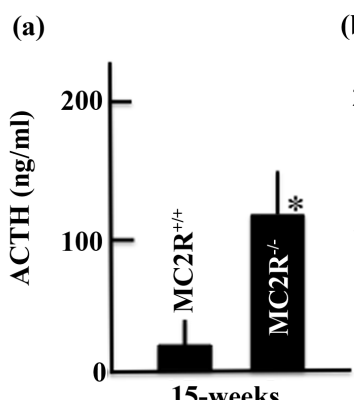

(b)

(e)

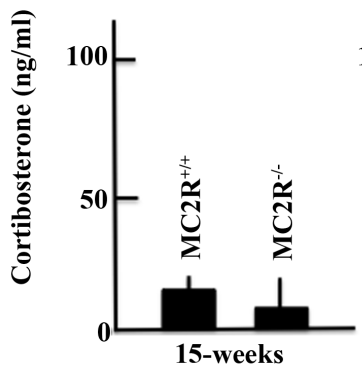

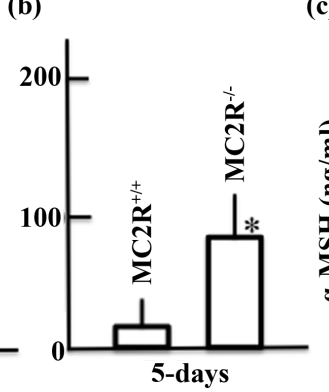

(f) (c)

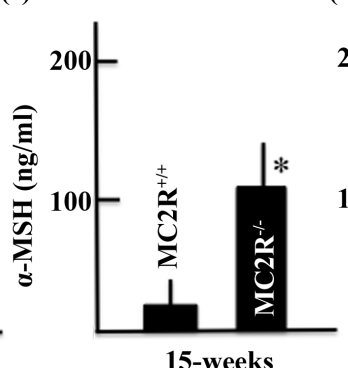

(d)

(g)

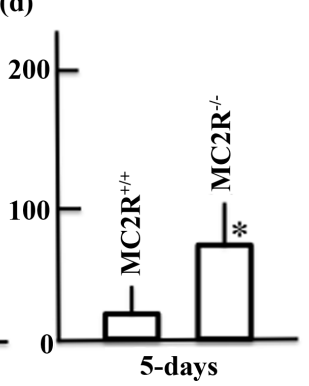

(h)
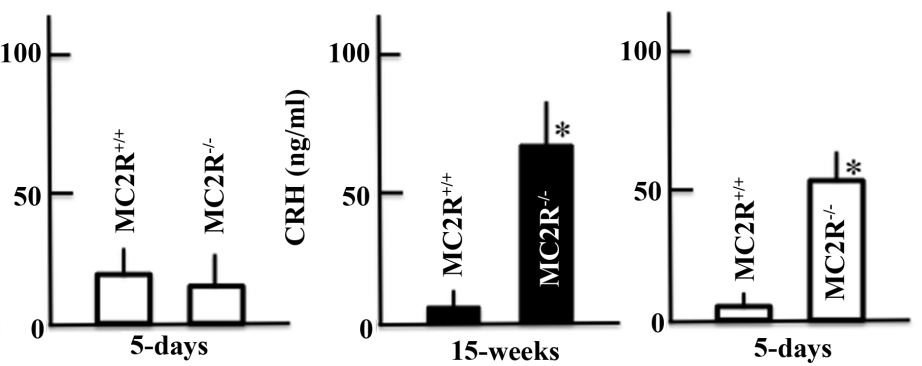

Figure 2. The effect of MC2R deficiency on the plasma levels of ACTH (a) and (b), $\alpha$-MSH (c) and (d), corticosterone (e) and (f) and CRH (g) and (h). The values are presented as the means \pm SD derived from ten animals. *, p $<0.05$.

week-old mice, the expression of PDE9A, MC1R and MC5R was increased in the MC2R $\mathrm{R}^{-/-}$mice compared with the $\mathrm{MC} \mathrm{R}^{+/+}$mice. In addition, the expression of the TGF- $\beta 2$ receptor was decreased in these mice compared with the $\mathrm{MC}^{-1 /-}$ mice (Figures 3(a)-(c)). On the other hand, in the five-day-old mice, the expression of Per1, Cry1 and the corticosterone receptor were decreased in the $\mathrm{MC}^{-\mathrm{R}^{--}}$mice compared with the levels in the MC2R $^{+/+}$mice (Figures 3(d)-(f)).

\subsection{Effects of LY83583, Anti-TGF- $\beta 1,2,3$, AgRP or Corticosterone Treatment on the Hair Cycle in the Dorsal Skin}

Fifteen-week-old $\mathrm{MC}_{2} \mathrm{R}^{-/}$mice exhibited primarily the anagen phase in the dorsal hair. However, treatment with AgRP (an inhibitor of MC1R and MC5R) and LY83583 (cGMP synthesis inhibitor) changed the hair cycle so that the hair was in the telogen phase (Figure 4(a)). These effects of the treatment were not seen in the five-day-old MC2R $\mathrm{R}^{-/-}$mice (Figure 4(b)). On the other hand, no changes in the hair cycle were observed in the 15-week-old $\mathrm{MC}^{-1-}$ mice following corticosterone treatment (Figure 4(a)). However, in the five-day-old $\mathrm{MC}_{2} \mathrm{R}^{-/-}$mice, the hair cycle shifted to the telogen phase (Figure 4(b)). In addition, in the $\mathrm{MC}^{\mathrm{R}} \mathrm{R}^{++}$mice, the hair cycle did not change from the telogen phase in response to any of the treatments.

\subsection{Quantification of the TGF- $\beta$ Level by an Enzyme-Linked Immunosorbent Assay}

In the 15-week-old MC2R ${ }^{-1-}$ mice, the concentration of TGF- $\beta$ in the plasma was increased by treatment with AgRP or LY83583 (Figure 5(a)). However, in the five-day-old MC2R ${ }^{-/-}$mice, the concentration of TGF- $\beta$ in the plasma did not change with either treatment (Figure 5(b)).

\section{Discussion}

The present study demonstrated that in the 15 -weeks-old $\mathrm{MC}^{-1-}$ mice, the hair cycle was in the anagen phase, and the hair cycle shifted to the telogen phase following treatment with an antagonist of MC1R and MC5R or a cGMP inhibitor. On the other hand, in the five-day-old $\mathrm{MC}^{-1-}$ mice, the hair cycle was shifted to the telogen phase following corticosterone administration. Moreover, an increase in the expression of clock genes was seen in these mice. It was thought that the hair cycle of the $\mathrm{MC}^{-1 /-}$ mice was controlled by a different mechanism at each age. 
It has been previously reported that ACTH starts from the point of POMC-induced anagen and has an important role in the process of hair growth [24]-[26]. By interacting with MC2R, ACTH can induce an elevation of the corticosterone level, and modulates the POMC system and local immune system [4] [27]. Therefore, increased plasma levels of corticosterone may cause a decrease in POMC-derived peptides in the skin, which is related to the anagen induction. However, since no MC2R was present in the MC2 ${ }^{-/-}$mice to induce the expression of corticosterone in response to ACTH exposure, no increase was observed in the corticosterone level in the blood, and there was no apparent feedback effect, suggesting that the POMC-derived peptides were maintained at high levels in the blood (Figure 1).

In the 15-week-old mice, the hair cycle was shifted to the telogen from the anagen phase by inhibiting other

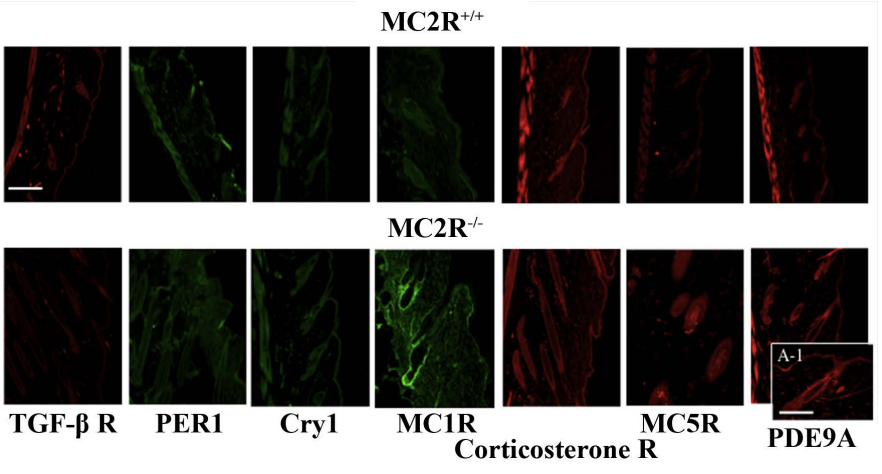

(a)

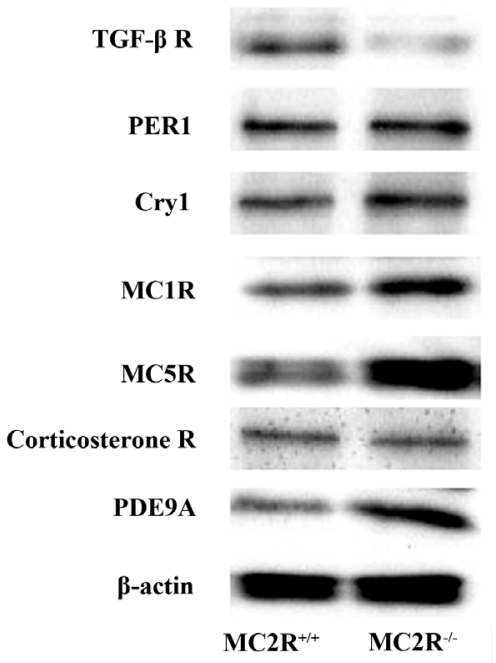

(b)

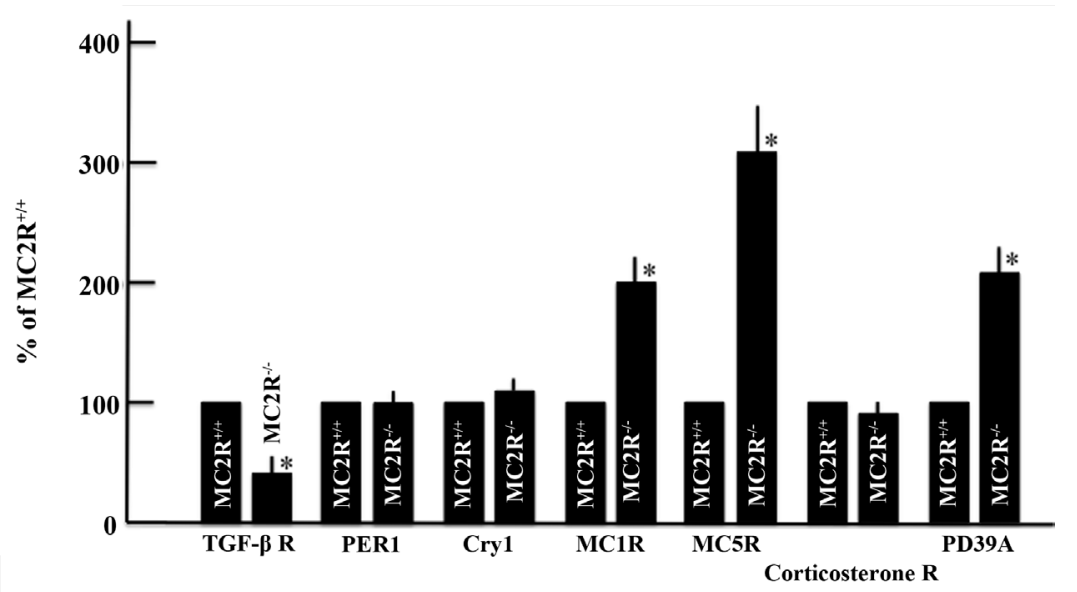

(c)

$M C 2 R^{+/+}$
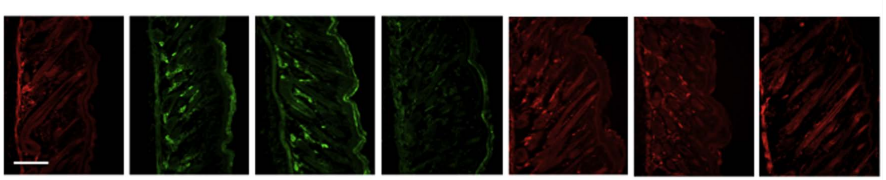

$\mathrm{MC}^{-1-}$
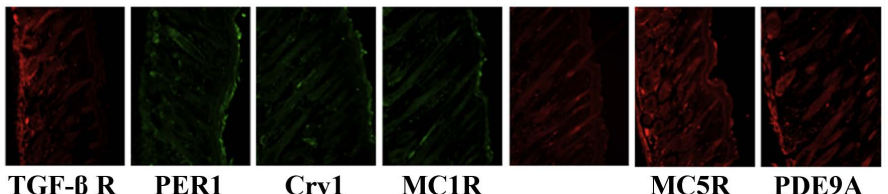

Corticosterone R

(d) 


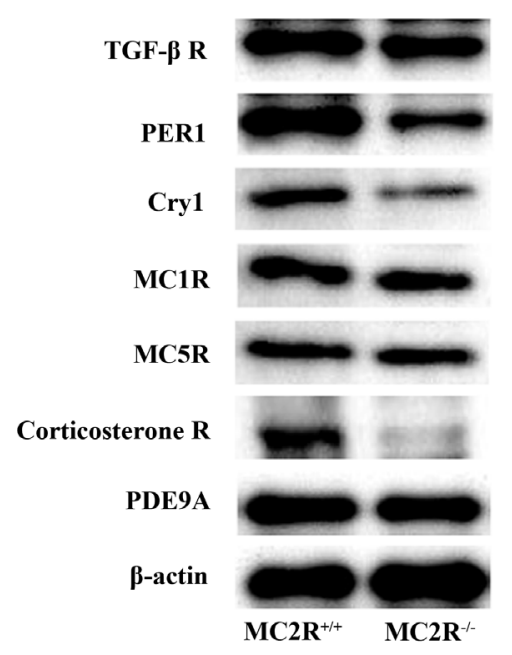

(e)

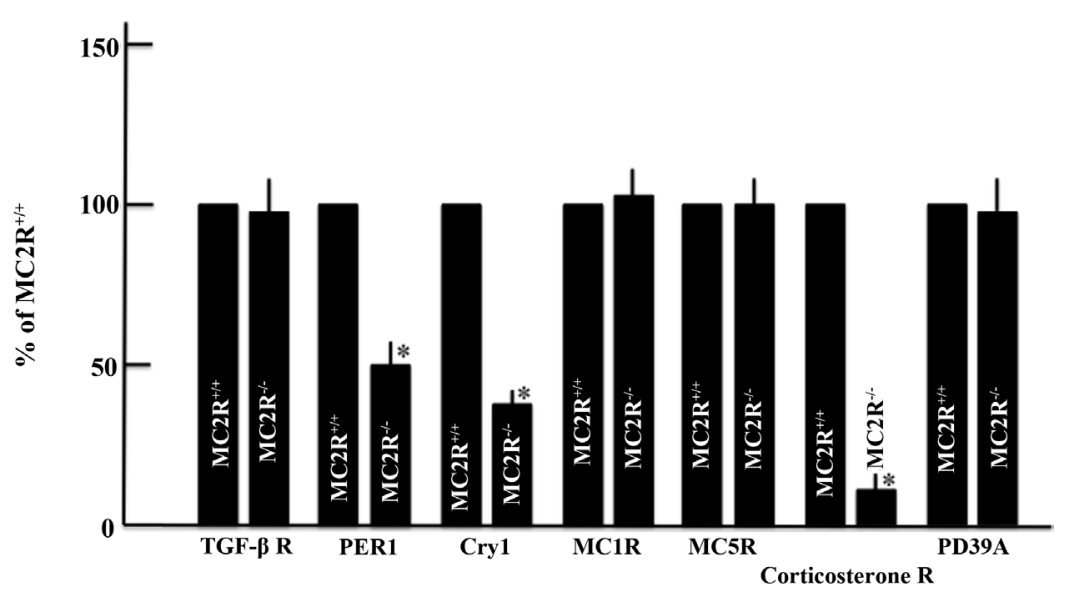

(f)

Figure 3. The expression levels of TGF- $\beta$, Per1, Cry1, MC1R, corticosterone R, MC5R and PDE9A in the MC2R ${ }^{+/+}$or $\mathrm{MC} 2 \mathrm{R}^{-1-}$ mice. We observed the expression of TGF- $\beta$, Per1, Cry1, MC1R, corticosterone R, MC5R and PDE9A in the dorsal skin of the MC2 $\mathrm{R}^{+/+}$and MC2R $\mathrm{R}^{-/-}$mice at 15-week-old (a)-(c) and five-day-old (d)-(f). The data show the results from one typical experiment involving ten animals. Scale bar $=100 \mu \mathrm{m}(\mathrm{a}-1 ; 200 \mu \mathrm{m})$. The values are presented as the mean $\pm \mathrm{SD}$ derived from 10 animals. *, $\mathrm{p}<0.05$.

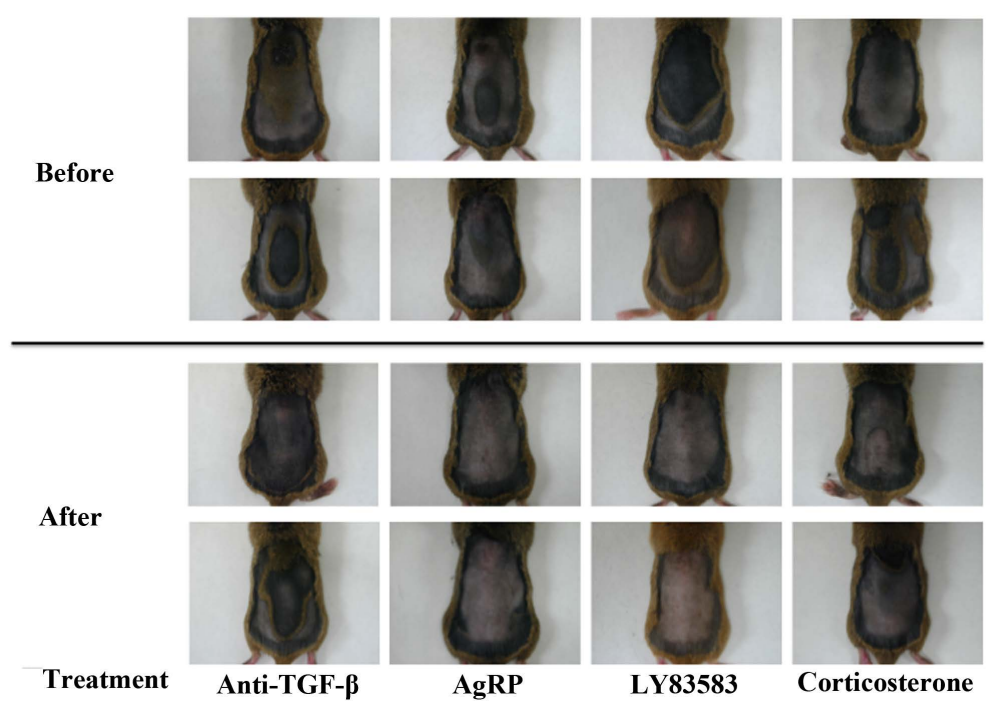

(a)

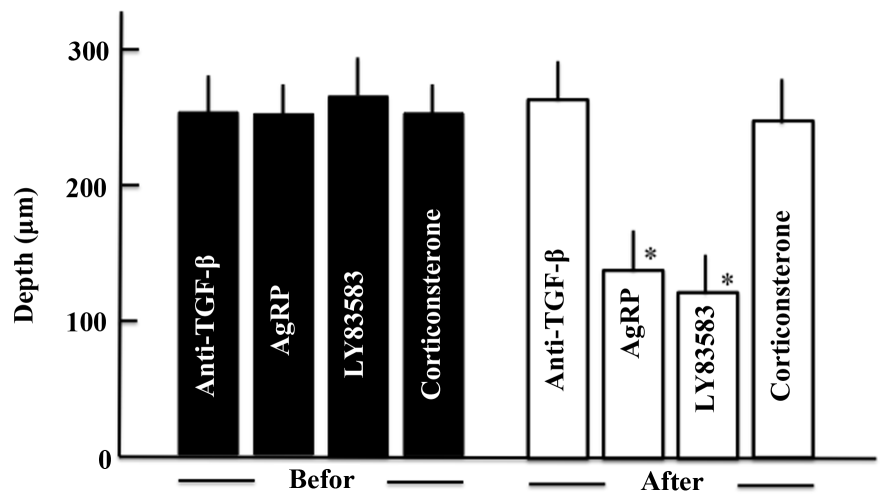

(b) 


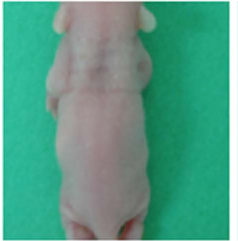

No-treatment

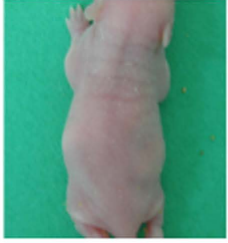

Anti-TGF- $\beta$

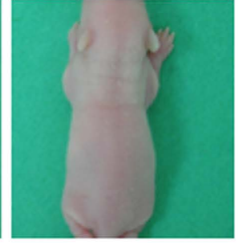

AgRP

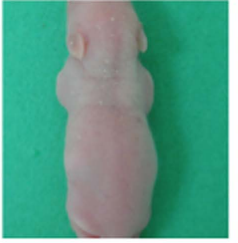

LY83583

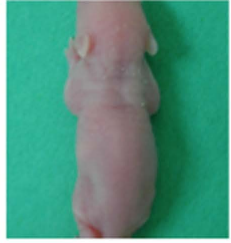

Corticosterone

(c)

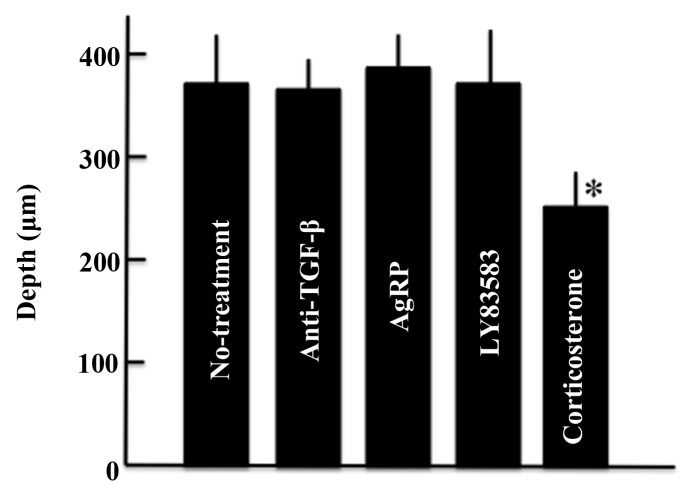

(d)

Figure 4. The effects of anti-TGF $\beta$, AgRP, LY83583 and corticosterone treatments on the hair cycle in MC2R ${ }^{-/-}$mice. In the 15-week-old $\mathrm{MC} 2 \mathrm{R}^{-1-}$ mice, the hair cycle shifted to the telogen phase after two weeks of AgRP or LY83583 administration (a) and (b). On the other hand, in the five-day-old MC2R ${ }^{-1-}$ mice, the hair growth was delayed by corticosterone administration (c) and (d). The data show two (one) typical experiment from 10 animals. The values are presented as the mean \pm SD derived from 10 animals. *, $\mathrm{p}<0.05$.

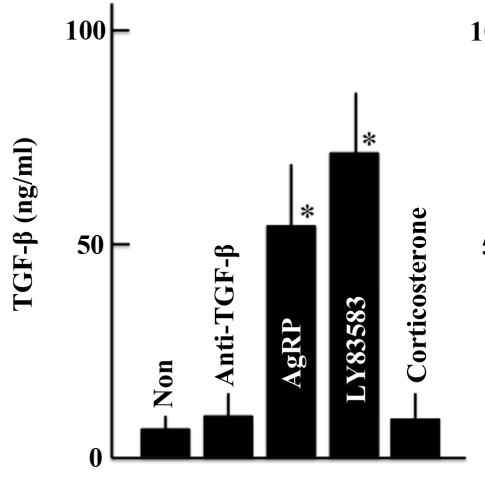

(a)

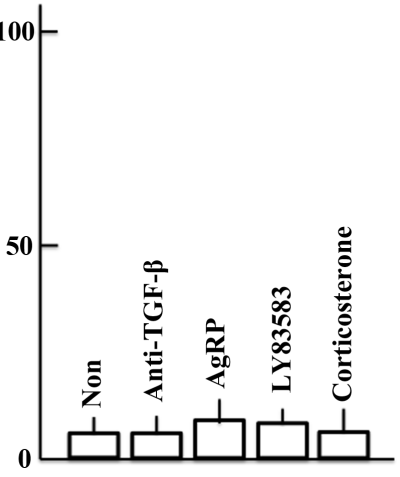

(b)

Figure 5. The effects of anti-TGF $\beta$, AgRP, LY83583 and corticosterone treatments on the plasma levels of TGF- $\beta$ in the MC2 $\mathrm{R}^{-1-}$ mice. (a) 15-week-old and (b) five-day-old MC2 $\mathrm{R}^{-/-}$mice. The values are presented as the means \pm SD derived from ten animals. $*$, $\mathrm{p}<0.05$.

receptors (MC1R and MC5R) for ACTH (Figure 4(a)). In addition, the hair cycle shift from the anagen to telogen phases was also caused by the administration of a cGMP inhibitor (Figure 4(a)). Therefore, it was thought that the hair cycle shifted from ACTH of a luxus by activating cGMP through MC1R and MC5R. In addition, there is a report in which the expression of MC1R mRNA was found to be related to the hair cycle [28]. Furthermore, ACTH inhibits the activity of TGF- $\beta$, which stops the hair cycle at the telogen phase [29].

In this study, the level of TGF- $\beta$ in the blood was increased by the administration of inhibitors of MC1R, MC5R and cGMP (Figure 5). Although it is possible that ACTH maintained the hair cycle in the anagen phase by suppressing the actions of TGF- $\beta$, the details underlying this mechanism are unclear. In addition, $\alpha$-MSH affects the cGMP level [30]. In the current study, a continuous increase in $\alpha$-MSH was observed in the $\mathrm{MC}^{-\mathrm{R}^{--}}$ 
mice compared with the $\mathrm{MC}^{+/+}$mice (Figure 2(c) and Figure 2(d)). Therefore, the increase in $\alpha$-MSH may also have influenced the duration of the anagen phase of the hair cycle.

On the other hand, in the five-day-old mice, the administration of inhibitors of the MCRs and cGMP did not affect the hair cycle. However, the retardation of the anagen phase was observed following the administration of corticosterone (Figure 4). Corticosterone is known to suppress the expression of clock genes (Per1, Clock, Cry1, etc.), but may conversely increase the expression of clock genes. The Per1 and Clock genes are expressed in hair follicles and modulate the hair cycle [31]. In the five-day-old $\mathrm{MC}^{-\mathrm{R}^{-/}}$mice, since there was little corticosterone, there was low expression of clock genes and the hair cycle shifted toward the anagen phase; however, following the administration of corticosterone, the expression of the clock genes increased, and as a result, the hair cycle shifted toward the telogen phase. Furthermore, the relationships between clock genes and melatonin are well known [32]-[34]. Melatonin activates pathways protective against oxidative stress, modifies cellular metabolism and is implicated in the hair growth cycle [35]. In the present experiment, a decrease in the expression of the clock gene was seen in the MC2R ${ }^{-/-}$mice (Figure 3(e) and Figure 3(f)). Therefore, melatonin may have an effect in reducing the expression levels of these clock genes. Moreover, in a previous study, when mice were kept in a dark place from birth, the expression of the clock genes was suppressed, and it was shown that the growth of the newborn's hair was delayed (data not shown). These results suggested that the clock genes are related to the hair cycle in newborn mice. On the other hand, there is a report that mast cells activate murine hair follicle regression [36]. In addition, corticosterone controls the expression of mast cells [37]. Therefore, depression of the corticosterone content in the $\mathrm{MC}^{-/-}$mice may have stopped remodeling of the hair follicle. Furthermore, CRH-R2 promotes the degradation of mast cells [38]. In the present study, the levels of CRH were increased in the MC2R ${ }^{-/}$mice (Figure 2(g) and Figure 2(h)). Although the expression of CRH-R was not investigated in this research, CRH/CRH-R may play a role in controlling the hair cycle. In the current experiments, we did not perform an examination of the immune system. Therefore, it is necessary to examine the immune system (especially mast cells) in future studies. Moreover, since this study is the research which used the mouse, it is difficult to actually transpose to human. Therefore, we are pleased if the research on people progresses based on the results of this study.

\section{Conclusion}

In this study, it was shown that the ACTH/MC2R system has an important role in the hair cycle. Moreover, the mechanism of action appears to change with age, with the ACTH/MC2R/cGMP/TGF- $\beta$ system functioning in adult mice, and the ACTH/MC2R/corticosterone/clock genes system being more active in the newborn mice. In this way, the hair cycle and neuroendocrine system exhibit a close relationship [39]. Elucidating the role of the MC2R signal is key to clarifying the complicated hair cycle.

\section{Conflict of Interest Statement}

The authors declare that they have no conflicts of interest.

\section{Authors' Contributions}

$\mathrm{KH}, \mathrm{KO}, \mathrm{YY}$ and EK performed the experiments; KH, YY and EK designed the research study; KH analyzed the data; KH and EK contributed essential reagents and tools; KH wrote the paper; and all authors approved of the submitted and final version manuscript.

\section{References}

[1] Aguilera, G. (1994) Regulation of Pituitary ACTH Secretion during Chronic Stress. Frontiersin Neuroendocrinology, 15, 321-350. http://dx.doi.org/10.1006/frne.1994.1013

[2] Slominski, A.T., Zmijewski, M.A., Zbytek, B., Tobin, D.J., Theoharides, T.C. and Rivier, J. (2013) Key Role of CRF in the Skin Stress Response System. Endocrine Reviews, 34, 827-884. http://dx.doi.org/10.1210/er.2012-1092

[3] Dallman, M.F. (1984) Control of Adrenocortical Growth in Vivo. Endocrine Research, 10, 213-242. http://dx.doi.org/10.1080/07435808409036499

[4] Dhabhar, F.S. and McEwen, B.S. (1999) Enhancing versus Suppressive Effects of Stress Hormone on Skin Immune Function. Proceedings of the National Academy of Sciences of the United States of America, 96, 1059-1064. 
http://dx.doi.org/10.1073/pnas.96.3.1059

[5] Arck, P.C., Handjiski, B., Peters, E.M., Prter, A.S., Hagen, E., Fischer, A., Klapp, B.F. and Paus, R. (2003) Stress Inhibits Hair Growth in Mice by Induction of Premature Catagen Development and Deleterious Perifollicular Inflammatory Events via Neuropeptide Substance P-Dependent Pathway. American Journal of Pathology, 162, 803-814. http://dx.doi.org/10.1016/S0002-9440(10)63877-1

[6] Peters, E.M., Arck, P.C. and Paus, R. (2006) Hair Growth Inhibition by Psychoemotional Stress: Mouse Model for Neural Mechanisms in Hair Growth Control. Experimental Dermatology, 15, 1-13. http://dx.doi.org/10.1111/j.0906-6705.2005.00372.x

[7] Arck, P.C., Handjiski, B., Hagen, E., Joachim, R., Klapp, B.F. and Paus, R. (2001) Inductions for a "Brain-Hair Follicle Axis (BHA)": Inhibition of Keratinocyte Proliferation and Up-Regulation of Kelatinocyte Apoptosis in Telogen hair Follicles by Stress and Substance P. FASEB Journal, 15, 2536-2538.

[8] Kimura-Ueki, M., Oda, Y., Oki, J., Komi-Kuramochi, A., Honda, E. and Asada, M. (2012) Hair Cycle resting phase is regulated by cycle epithelial FGF18 signaling. Journal of Investigative Dermatology, 132, 1338-1345. http://dx.doi.org/10.1038/jid.2011.490

[9] Foitzik, K., Lindner, G., Mueller-Roever, S., Maurer, M., Botchkareva, N., Botchkarev, V., Handjiski, B., Metz, M., Hibino, T., Soma, T., Dotto, G. P. and Paus, R. (2000) Control of Murine Hair Follicle Regression (Catagen) by TGFbeta1 in Vivo. FASEB Journal, 14, 752-760.

[10] Naito, A., Sato, T., Matsumoto, T., Takeyama, K., Yoshino, T., Kato, S. and Ohdera, M. (2008) Dihydrotestosterone Inhibits Murine Hair Growth via the Androgen Receptor. British Journal Dermatology, 59, 300-305. http://dx.doi.org/10.1111/j.1365-2133.2008.08671.x

[11] Tomita, Y., Akiyama, M. and Shimizu, H. (2006) PDGF Isoforms Induce and Maintain Anagen Phase of Murine Hair Follicles. Journal of Dermatological Science, 43, 105-115. http://dx.doi.org/10.1016/j.jdermsci.2006.03.012

[12] Hayashi, Y., Yamamoto, N., Nakagawa, T. and Ito, J. (2013) Insulin-Like Growth Factor 1 Inhibits Hair Cell Apoptosis and Promotes the Cell Cycle of Supporting Cells by Activating Different Downstream Cascades after Pharmacological Hair Cell Injury in Neonatal Mice. Molecular and Cellular Neuroscience, 56, 29-38. http://dx.doi.org/10.1016/j.mcn.2013.03.003

[13] Katayama, M., Aoki, E., Suzuki, H. and Kawana, S. (2007) Foot Shock Stress Prolongs the Telogen Stage of the Spontaneous Hair Cycle in a Non-Depilated Mouse Model. Experimental Dermatology, 16, 553-560. http://dx.doi.org/10.1111/j.1600-0625.2007.00558.x

[14] Aoki, E., Shibasaki, T. and Kawana, S. (2003) Intermittent Foot Shock Stress Prolongs the Telogen Stage in the Hair Cycle of Mice. Experimental Dermatology, 12, 371-377. http://dx.doi.org/10.1034/j.1600-0625.2002.120403.X

[15] Liu, N., Wang, L.H., Guo, L.L., Wang, G.Q., Zhou, X.P., Jiang, Y., Shang, J., Murao, K., Chen, J.W., Fu, W.Q. and Zhang, G.X. (2013) Chronic Restraint Stress Inhibits Hair Growth via Substance P Mediated by Reactive Oxygen Species in Mice. PLoS One, 8, e61574. http://dx.doi.org/10.1371/journal.pone.0061574

[16] Roloff, B., Fechner, K., Slominski, A., Furkert, J., Botchkarev, V.A., Bulfone-Paus, S., Zipper, J., Krause, E. and Paus, R. (1998) Hair Cycle-Dependent Expression of Corticotropin-Releasing Factor (CRF) and CRF Receptors (TCRF-R) in Murine Skin. FASEB Journal, 12, 287-297.

[17] Chida, D., Nakagawa, S., Nagai, S., Sagara, H., Katsumata, H., Imaki, T., Suzuki, H., Mitani, F., Ogishima, T., Shimizu, C., Kotaki, H., Kakuta, S., Sudo, K., Koike, T., Kubo, M. and Iwakura, Y. (2007) Melanocortin 2 Receptor Is Required for Adrenal Gland Development, Steroidogenesis, and Neonatal Gluconeogenesis. Proceedings of the National Academy of Sciences of the United States of America, 104, 18205-18210. http://dx.doi.org/10.1073/pnas.0706953104

[18] Fleisch, J.H., Haisch, K.D., Spaethe, S.M., Rinkema, L.E., Cullinan, G.J., Schmidt, M.J. and Marshall, W.S. (1984) Pharmacologic Analysis of Two Novel Inhibitors of Leukotriene (Slow Reacting Substance) Release. Journal of Pharmacology and Experimental Therapeutics, 229, 681-689.

[19] Linke, A., Goren, I., Bosl, M.R., Pfeilschifter, J. and Frank, S. (2010) Epithelial over Expression of SOCS-3 in Transgenic Mice Exacerbates Wound Inflammation in the Presence of Elevated TGF- $\beta 1$. Journal of Investigative Dermatology, 130, 866-875. http://dx.doi.org/10.1038/jid.2009.345

[20] Hiramoto, K., Kobayashi, H., Ishii, M., Sato, E. and Inoue, M. (2010) Increased Alpha-Melanocyte-Stimulating Hormone ( $\alpha$-MSH) Levels and Melanocortin Receptors Expression Associated with Pigmentation in an NC/Nga Mou- se Model of Atopic Dermatitis. Experimental Dermatology, 19, 132-136. http://dx.doi.org/10.1111/j.1600-0625.2009.00988.x

[21] Herrmann, M., Henneicke, H., Street, J., Modzelewski, J., Kalak, R., Buttgereit, F., Dunstan, C.R., Zhou, H. and Seibel, M.J. (2009) The Challenge of Continuous Exogenous Glucocorticoid Administration in Mice. Steroids, 74, $245-249$. http://dx.doi.org/10.1016/j.steroids.2008.11.009 
[22] Muller-Rover, S., Handjiski, B., van der Veen, C., Eichmuller, S., Foitzik, K., McKay, I.A., Stenn, K.S. and Paus, R. (2001) A Comprehensive Guide for the Accurate Classification of Murine Hair Follicles in Distinct Hair Cycle Stages. Journal of Investigative Dermatology, 117, 3-15. http://dx.doi.org/10.1046/j.0022-202x.2001.01377.x

[23] Ito, T., Ito, N., Saathoff, M., Bettermann, A., Takigawa, M. and Paus, R. (2005) Interferon-Gamma Is a Potent Inducer of Catagen-Like Changes in Cultured Human Anagen Hair Follicles. British Journal of Dermatology, 152, 623-631. http://dx.doi.org/10.1111/j.1365-2133.2005.06453.x

[24] Paus, R., Maurer, M., Slominski, A. and Czarnetzki, B.M. (1994) Mast Cell Involvement in Murine Hair Growth. Developmental Biology, 163, 230-240. http://dx.doi.org/10.1006/dbio.1994.1139

[25] Slominski, A., Botchkareva, N.V., Botchkarev, V.A., Chakraborty, A., Luger, T., Uenalan, M. and Paus, R. (1998) Hair Cycle-Dependent Production of ACTH in Mouse Skin. Biochimica et Biophysica Acta, 1448, 147-152. http://dx.doi.org/10.1016/S0167-4889(98)00124-4

[26] Slominski, A., Paus, R. and Mazurkiewicz, J. (1992) Proopiomelanocortin expre ssion in the Skin during Induced Hair Growth in Mice. Experientia, 48, 50-54. http://dx.doi.org/10.1007/BF01923606

[27] Slominski, A., Wortsman, J., Luger, T., Paus, R. and Solomon, S. (2000) Corticotropin Releasing Hormone and Proopiomelanocortin Involvement in the Cutaneous Response to Stress. Physiological Reviews, 80, 979-1020.

[28] Ermak, G. and Slominski, A. (1997) Production of POMC, CRH-R1, MC1, and MC2 Receptor mRNA and Expression of Tyrosinase Gene in Relation to Hair Cycle and Dexamethasone Treatment in the C57BL/6 Mouse Skin. Journal of Investigative Dermatology, 108, 160-165. http://dx.doi.org/10.1111/1523-1747.ep12332925

[29] Stankovic, A.K., Grizzie, W.E., Stockard, C.R. and Parker Jr., C.R. (1994) Interactions between TGF-Beta and Adrenocorticotropic in Growth Regulation of Human Adrenal Fetal Zone Cells. American Journal of Physiology, 266, E495-E500.

[30] Lezcano, N.E. and Celis, M.E. (1996) Effects of Alpha-MSH and Cholinergic Agents on cGMP and IP3 Levels in Rat Brain Slices. Acta Physiologica, Pharmacologica et Therapeutica Latinoamericana, 46, 193-201.

[31] Al-Nuaimi, Y., Hardman, J.A., Biro, T., Haslam, I.S., Philpott, M.P., Toth, B.I., Farjo, N., Farjo, B., Baier, G., Watson, R.E., Grimaldi, B., Kloepper, J.E. and Paus, R. (2014) A Meeting of Two Chronobiological Systems: Circadian Proteins Period1 and BMAL1 Modulate the Human Hair Cycle Clock. Journal of Investigative Dermatology, 134, 610619. http://dx.doi.org/10.1038/jid.2013.366

[32] Christ, E., Pfeffer, M., Korf, H.W. and Van Gall, C. (2010) Pineal Melatonin Synthesis Is Altered in Period1 Deficient Mice. Neuroscience, 171, 398-406. http://dx.doi.org/10.1016/j.neuroscience.2010.09.009

[33] Dinet, V. and Korf, H.W. (2007) Impact of Melatonin Receptors on pCREB and Clock-Gene Protein Levels in the Musine Retina. Cell and Tissue Research, 330, 29-34. http://dx.doi.org/10.1007/s00441-007-0468-5

[34] Yasuo, S., Von Gall, C., Weaver, D.R. and Korf, H.W. (2008) Rhythmic Expression of Clock Genes in the Ependymal Cell Layer of the Third Ventricle of Rodents Is Independent of MELATONIN signaling. European Journal of Neuroscience, 28, 2443-2450. http://dx.doi.org/10.1111/j.1460-9568.2008.06541.x

[35] Slominski, A., Wortsman, J. and Tobin, D.J. (2005) The Cutaneous Serotoninergic/Melatoninergic System: Securing a Place Under the Sun. FASEB Journal, 19, 176-194. http://dx.doi.org/10.1096/fj.04-2079rev

[36] Maurer, M., Fischer, E., Handjiski, B., von Stebut, E., Algermissen, B., Bavandi, A. and Paus, R. (1997) Activated Skin Mast Cells Are Involved in Murine Hair Follicle Regression (Catagen). Laboratory Investigation, 77, 319-332.

[37] Diaz, B., Barreto, E., Cordeiro, R., Perretti, M., Martins, M. and Silva, P. (2001) Enhanced Serum Glucocorticoid Levels Mediate the Reduction of Serosal Mast Cell Numbers in Diabetic Rats. Life Sciences, 8, 2925-2932. http://dx.doi.org/10.1016/S0024-3205(01)01087-6

[38] Hashimoto, K., Makino, S., Asaba, K. and Nishiyama, M. (2001) Physiological Roles of Corticotropin-Releasing Hormone Receptor Type 2. Endocrine Journal, 48, 1-9. http://dx.doi.org/10.1507/endocrj.48.1

[39] Paus, R., Langan, E.A., Vidali, S., Ramot, Y. and Andersen, B. (2014) Neuroendocrinology of the Hair Follicle: Principles and Clinical Perspectives. Trends in Molecular Medicine, 20, 559-570. http://dx.doi.org/10.1016/j.molmed.2014.06.002 